Heavy Metals Tolerance and Antibiotics Susceptibilty Profiles of Staphylococcus aureus Strains Isolated From Clinical Sources in Baquba city

Lina Abdulameer Salman Alsaadi

\title{
Heavy Metals Tolerance and Antibiotics Susceptibilty Profiles of Staphylococcus aureus Strains Isolated from Clinical Sources in Baquba city
}

\author{
Lina Abdulameer Salman Alsaadi \\ Department of Biology - College of Science - Diyala University - Iraq
}

Received: 28 March 2016

Accepted: 5 April 2016

\section{$\underline{\text { Abstract }}$}

Twenty- one Staphylococcus aureus isolated from various clinical samples (wound, ear, pus, urin and burn ) collected from Baquba General Hospital over a period ( April 2015 to June 2015 ).Out of 21 Staphylococcus aureus isolates , 17 (80.95\%) were resistant to methicillin , while 4 (19.04\%) were methicillin susceptible. Results of antimicrobial susceptibility showed high resistance to amoxicillin, amoxicillin/clavulanic acid, trimethoprime and cefotaxime with ratio $100 \%, 76.1 \%, 76.1 \%$ and $71.4 \%$ respectively, while isolates resistant oflaxacin with $4.7 \%$. The results showed that 15 isolates of the total (21) of Staphylococcus aureus could produce $\beta$ lactamase with percentage $(71.4 \%), 5$ isolates produce of Metallo $\beta$-lactamase with $(23.80 \%)$ , and 4 isolates (19.04\%) produce ES $\beta$ Ls. Staphylococcus aureus isolates have ability to tolerant the highest concentration of heavy metals like (Cobalt, Copper, iron, Mercury, Zinc) with ratio $(57.1 \%, 52.3 \%, 66.6 \%, 33.3 \%, 61.9 \%)$ respectively. Additionally result of plasmid profile presented that all isolates of Staphylococcus aureus contained two band s of plasmid vary in size . Plasmid curing was carried out by acridin orang $(256 \mu \mathrm{g} / \mathrm{ml})$, cobalt and zinc resistance character was found to be present on the chromosomal DNA rather than the plasmid DNA whereas iron, copper and mercury resistance characters were found to be present on the plasmid . Curing result showed the loss of antibiotic and heavy metal resistance property for 
Heavy Metals Tolerance and Antibiotics Susceptibilty Profiles of Staphylococcus aureus Strains Isolated From Clinical Sources in Baquba city

\title{
Lina Abdulameer Salman Alsaadi
}

(cefotaxim, amoxicillin, erythromycin, ciprofloxacin, iron, copper and mercury) from the isolates and confirms a relationship between antibiotic and heavy metal resistance with plasmid. Key words : Staphylococcus aureus, Heavy Metals, Antibiotics, Curing, Plasmid .

\section{Staphylococcus aureus نسق التحمل للمعادن الثقيلة والحساسية للمضادات الحيوية لبكتريا المعزولة من مصادر سريرية في مدينة بعقوبة .}

\author{
لينا عبدالامير سلمان السعدي \\ العراق- جامعة ديالى ـ كلية العلوم -قسم علوم الحياة
}

\section{الخلاصة}

جمعت احدى و عشرون عزلة من المكورات العنقودية الذهبية من مصادر سريرية مختلفة شملت ( الجروح ، الاذن ، القيح ،

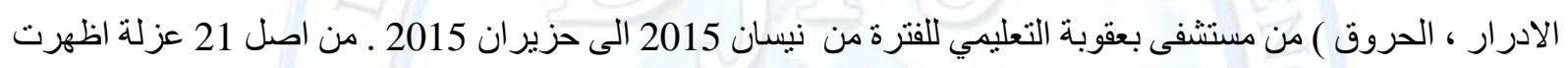
17 عزلة (80.95\%) مقاو مة للمثنيلين بينما 4 عز لات ( $19.04 \%$ ) حساسة للمثيسيلين . اظهرت نتائج الحساسية للمضادات الحيوية مقاومة عالية لمضادات amoxicillin/clavulanic acid و و و و و و

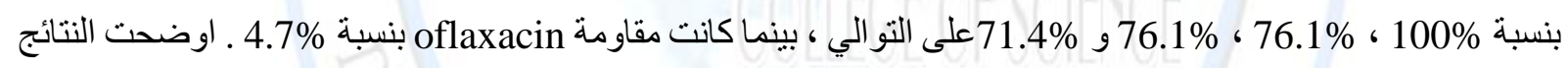
ان 15 عزلة (71.4\%) من اصل 21 عزلة تنتج انزيمات البيتالاكتاميز و 5 عزلات قادرة على انتاج انزيمات البيتالاكتاميز المعدنية بنسبة 23.80\% و 4 عزلات (19.04\%) تنتج انزيمات البيتالاكتاميز واسعة الطيف ـ اظهرت بكتريا zinc ، mercury ، iron ، copper ، cobalt ( قابلية تحمل اعلى تركيز من المعادن الثقيلة Staphylococcus aureus

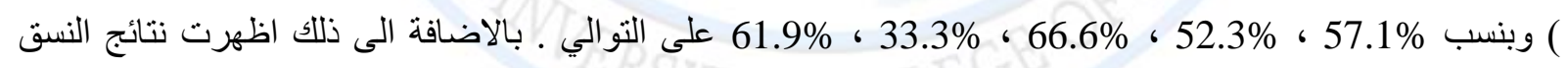
البلازميدي احتو اء بكتريا Staphylococcus aureus على حزمنين بلازميديتين مختلفة الحجم ـ تمكنت مادة الاكريدين

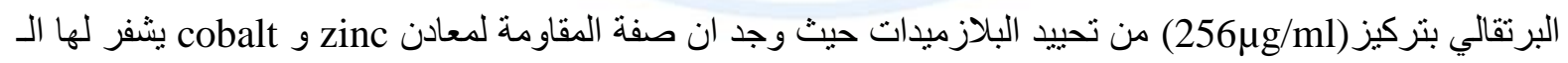
mercury و copper ، iron الكروموسومي وليس البلازميدي ، بينما صوفة المقاومة لمعادة على البلازميد

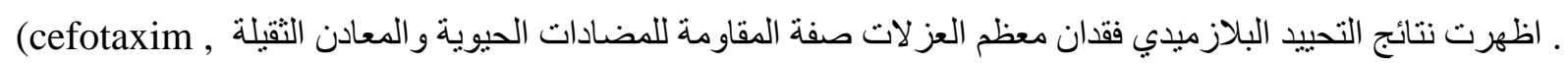
(amoxicillin , erythromycin , ciprofloxacin , iron , copper and mercury

$$
\text { مقاومة المعادن الثقبلة و المضادات مع البلازميدات. }
$$

الكلمات المفتاحية : Staphylococcus aureus ، المعادن الثقبلة ، المضادات الحيوية ، التحييد ، البلازميدات. 


\section{Heavy Metals Tolerance and Antibiotics Susceptibilty Profiles of Staphylococcus aureus Strains Isolated From Clinical Sources in Baquba city}

Lina Abdulameer Salman Alsaadi

\section{Introduction}

Staphylococcus aureus is a Gram-positive bacterium acting as one of the main pathogens that can cause various forms of diseases associated with wound infection, skin infection, soft tissue and more serious sequelae such as urinary tract infection, septicemia, osteomylitis and endocarditis $(1,2)$. Multidrug resistance is very common in Staphylococcus aureus clinical isolates worldwide, particularly in developing countries (3). Methicillin-resistant Staphylococcus aureus ( MRSA ) isolates have been associated with nosocomial infections and rapidly developed resistance to multiple drug classes and is now regaded as a major hospital acquired pathogen worldwide $(4,5)$, MRSA not only resistance to methicillin, but it also resistant to many groups of antibiotics, such as ciprofloxacin, co-trimoxazole and gentamicin $(6,7)$. Heavy metals have been found in increasing proportions in microbial habitates as a result of rapid urbanization and natural processes (8). Metals like copper, nickel, iron, zinc and cobalt play important role both directly or indirectly in almost all metabolic processes, growth and development of microorganisms (9). However increase in the concentration of the metals beyond tolerance levels have forced these microorganisms to adapt using various biological mechanisms in other withstand the condition of the increased concentrations $(9,10)$. the growth inhibition mechanism have been involved the entrance of heavy metals ions $\left(\mathrm{Cu}^{+2}, \mathrm{Cd}^{+2}, \mathrm{Zn}^{+2}\right.$ , $\mathrm{Ag}^{+}$etc. ) leads to the formation of secondary metabolites, subsequently constituting the compounds toxic to the microorganism (11). S. aureus was reported to be resistant to anumber of metals such as iron and chromium (12). Many mechanisms enable microbes to adapt with heavy metals presence included: accumulation and uptake, mineralization, complexation, metal efflux systems, reduction of metal ions or utilization of the metal as a terminal electron accepter during an aerobic respiration and metal sorption $(13,14)$.

Microorganisms that can grow and tolerate in the presence of high concentration of heavy metals play an important role in their biological cycling which has great potential in bioremediation of environment contaminated with heavy metals (15). Metal resistance in bacteria is mostly plasmid - encoded (16), the goal of this research is to analyze the antibiotics sensitivity patterns, tolerance of heavy metals and the relationship between heavy metal and antibiotic resistance with DNA plasmid in S. aureus isolates . 
Heavy Metals Tolerance and Antibiotics Susceptibilty Profiles of Staphylococcus aureus Strains Isolated From Clinical Sources in Baquba city

Lina Abdulameer Salman Alsaadi

\section{Materials and Methods}

\section{Media and Chemicals}

Mueller-Hinton agar, Nutrient agar , Nutrient broth, Manitol salt agar and Agarose from Oxoid - England , acridine orange , EDTA , cobalt , iron , copper , zinc , Mercury from BDH England, Antibiotics from Oxoid - England.

\section{Identification of Bacterial Isolates}

Twenty- one Staphylococcus aureus isolates from various clinical samples (wound, ear, pus , urin , burn ) collected from Baquba General Hospital over a period of three months (April 2015 to june 2015 ) were inoculated into nutrient agar ( as slant ) and incubated at $37^{\circ} \mathrm{C}$ for 24 h. S. aureus isolates were identified by Gram stain, manitol fermentation, coagulase test, catalase test and colony morphology on manitol salt agar (17).

\section{Antibiotic Susceptibility Testing}

Eleven antibiotics including Methicillin (MC) $5 \mu \mathrm{g}$, Amoxicillin (AX) $25 \mu \mathrm{g}$, AmoxicillinClavulanic acid (augmentin) (AMC) $30 \mu \mathrm{g}$, Cefotaxime (CTX) $30 \mu \mathrm{g}$, Pipracillin (PRL) 30 $\mu \mathrm{g}$, Oflaxacin (OF) $5 \mu \mathrm{g}$, Gentamicin ( CN) $10 \mu \mathrm{g}$, Ciproflxacin (CIP) $5 \mu \mathrm{g}$, Erythromycin (E) $15 \mu \mathrm{g}$, Trimethoprim (TMP) $10 \mu \mathrm{g}$, and Vancomycin (VA) $30 \mu \mathrm{g}$ have been tested in order to test the sensitivity of Staphylococcus aureus dy using the Mueller-Hinton agar plates . The interprentation of inhibition zones around the disc is according to the guidelines of the National Committee for Clinical Laboratory Standards ( CLSI ) $(18,19)$.

\section{Detection of $\beta$-lactamase, Metallo $\beta$-lactamase and ES $\beta$ Ls Production.}

The iodometric method for detection of $\beta$-lactamase was described by (WHO) 1978 (20). Detection of Metallo $\beta$-lactamase by using Imipenem EDTA combined disk test (21), using two Imipenem disk $(10 \mu \mathrm{g})$ with $3 \mathrm{~cm}$ between them , and then the $(10 \mu \mathrm{g})$ EDTA solution to one of the drives of Imipenem then incubated at a temperature $37^{\circ} \mathrm{C}$ for $18-24$ hour, after observing areas of inhibition zone, increase of inhibition zone above $7 \mathrm{~mm}$ on the disk Imipenem with EDTA compaired with the Imipenem disk alone, the result is positive . Disk Approximation 
Heavy Metals Tolerance and Antibiotics Susceptibilty Profiles of Staphylococcus aureus Strains Isolated From Clinical Sources in Baquba city

Lina Abdulameer Salman Alsaadi

method was performed for detection of ES $\beta$ Ls for all isolates which were positive to $\beta$ lactamase production (22).

\section{Tolerance of Heavy Metals Salts}

The two-fold agar dilution susceptibility method is used for determination tolerance of each Staphylococcus aureus strains to five metal salts $\left(\mathrm{CoCl}_{2} \cdot \mathrm{CH}_{2} \mathrm{O}, \mathrm{FeCl}_{3}, \mathrm{CuCl}_{2} \cdot 2 \mathrm{H}_{2} \mathrm{O}, \mathrm{ZnCl}_{2}\right.$ and $\mathrm{HgCl}_{2}$ ). Different concentration of salts of heavy metals ranged between $0.005 \mathrm{mM}$ to $4.5 \mathrm{mM}$ of each metal . Resistant strains were always possible to revitalize using pure medium without addition of metal . The plates were incubated at $37^{\circ} \mathrm{C}$ and observed for growth antimicrobial activity was expressed in terms of zone of inhibition ( $\mathrm{mm})$. Each experiment was repeated twice and average was taken (23).

\section{Plasmid Profile ( Plasmid DNA analysis )}

Plasmid DNA of the four isolates are extracted using the Pure Yield ${ }^{\mathrm{TM}}$ Plasmid Miniprep Kit ( Promega U.S.A ). Plasmid DNA was analyzed by electrophoresis on $0.7 \%$ agarose gel containing $0.5 \mu \mathrm{g}$ of ethidium bromide per $\mathrm{ml}(24)$. And pass the electricity ( $7 \mathrm{volt} / \mathrm{cm}^{2}$ ) for (11.5) hour, the agarose have been tested by using ultra violete transilluminator in wave length (320nm).

\section{Curing of Plasmid DNA}

Curing was conducted by using different concentrations of Acridin orange $(64,128,256,512$ $, 1024,2000) \mu \mathrm{g} / \mathrm{ml}(24)$. The tubes were incubated at $37^{\circ} \mathrm{C}$ for $24 \mathrm{~h}$, the cured isolates were checked for their antibiotic sensitivity and heavy metal tolerating capacity.

\section{$\underline{\text { Results and Discussions }}$}

\section{Isolation and Identification of Staphylococcus aureus}

Twenty- one isolates of Staphylococcus aureus were obtained from the total 84 clinical specimens (wound, ear, pus, urin, burn ). Diagnosis was confirmed by using regular apistaph system . Classified all isolates of $S$. aureus by positions of infection ( Table 1 ), The results showed that the largest proportion of the isolates were within wound samples 7( $33.33 \%$ ) isolates of the total, while the proportion of the isolates in the ear samples 5 ( $23.80 \%$ ) isolate 
Heavy Metals Tolerance and Antibiotics Susceptibilty Profiles of Staphylococcus aureus Strains Isolated From Clinical Sources in Baquba city

Lina Abdulameer Salman Alsaadi

, in cases of urin and pus were $4(19.04 \%)$, wheals the proportion of the isolates in the burns samples were 1 (4.76\%). These results have the agreement with Imran et al (5) who indicated that the hight rate of infection with S.aureus was found in wound samples (25\%), followed by ear swab (20\%), pus swab (18\%) and urin (17\%), and also these results are agreed partially with Obiazi et al (25) pointed out that the highest rate of infection with S.aureus were from infections of wounds, which amounted to (12) case (48\%), followed by cases of infections at the urinary tract as it amounted to (8) isolated (40\%).

Table (1): The number of isolates and ratios as sites of infection

\begin{tabular}{|c|c|c|}
\hline Type of Clinical Sources & Number of Staphylococcus aureus Isolates & Percentage (\%) of Isolates \\
\hline Wound swab & 7 & $33.33 \%$ \\
\hline Ear swab & 5 & $23.80 \%$ \\
\hline Urin & 4 & $19.04 \%$ \\
\hline Pus swab & 4 & $19.04 \%$ \\
\hline Burn swab & 1 & $4.76 \%$ \\
\hline Total & 21 & $100 \%$ \\
\hline
\end{tabular}

\section{Antimicrobial Susceptibility test}

The results of antimicrobial susceptibility test showed that 17 isolates $(81 \%)$ were found to be resistant to methicillin, while 4 isolates (19\%) were sensitive. this percentage agreed with the resuls of El-Gayar et al (26) demonstrated the ratio of methicillin resistance in this amounted $(81.4 \%)$, while (18.6\%) were sensitive.Sensitivity of S. aureus aginst (12) antibiotic are tested , which common types in use in our country for treatment of various infection, the results showed all isolates has resistance to amoxicillin with ratio 100\% (Figure 1), and these results are consistant with Imran et al (5) pointed out that S.aureus were resistant to amoxicillin with $100 \%$. S.aureus isolates showed resistance to amoxicillin/clavulanic acid and trimethoprime with $76.1 \%$, while S. aureus resists cefotaxime, erythromycin, piperacillin with $71.4 \%$, $61.9 \%, 57.1 \%$ respectively . The results showed that S.aureus resist Ciprofloxacin with 38\%, while resistance of aminoglycoside group including gentamicin was 52.3\% . This isolates resists vancomycin and oflaxacin with $23.8 \%, 4.7 \%$ respectively(Figure 1). This resistance may due to change in permeability of the outer membrane, as well as the secretion of $\beta$ laclamase enzymes and efflux pump system (27). 
Heavy Metals Tolerance and Antibiotics Susceptibilty Profiles of Staphylococcus aureus Strains Isolated From Clinical Sources in Baquba city

Lina Abdulameer Salman Alsaadi

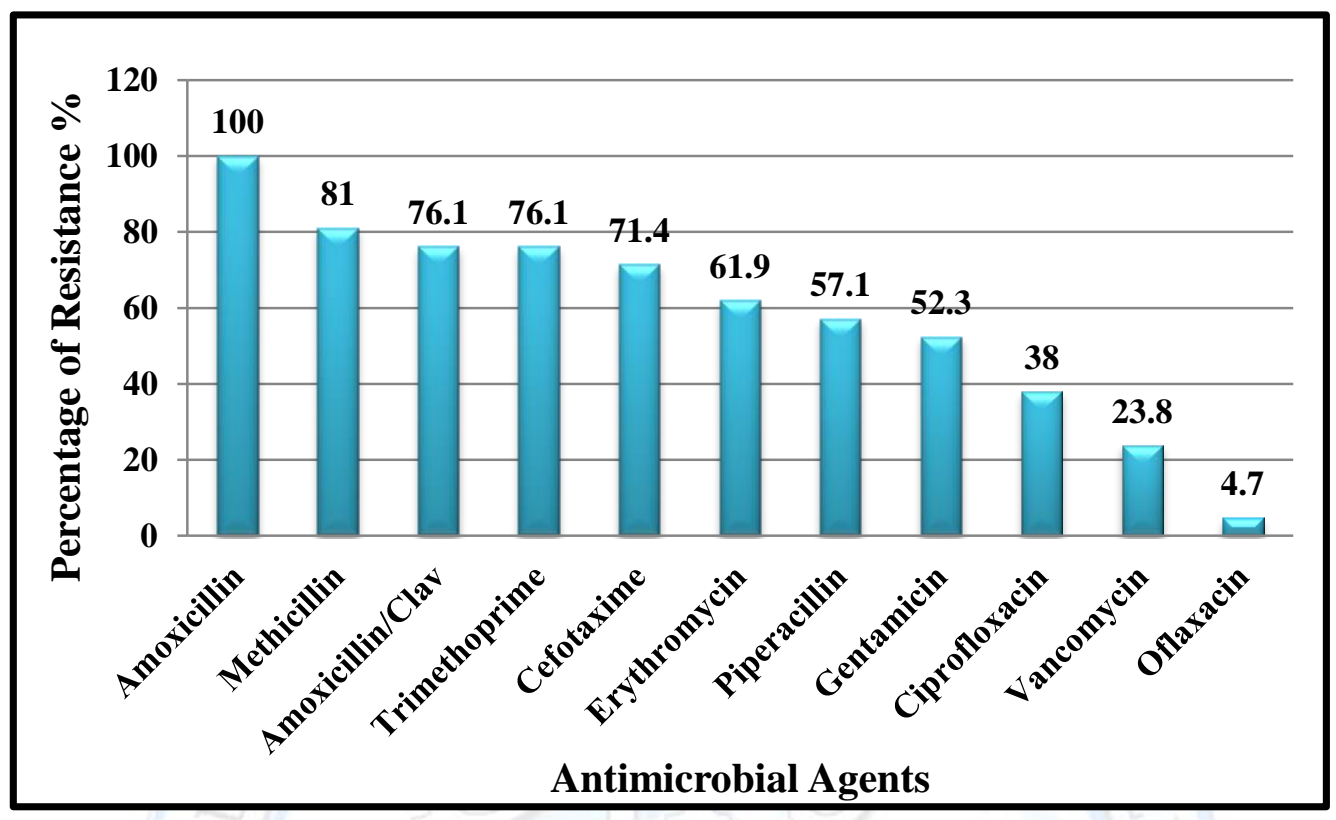

Figure (1): Antibiotic resistance pattern of Staphylococcus aureus .

\section{Detection of $\beta$-lactamase, Metallo $\beta$-lactamase and ES $\beta$ L Production.}

The results showed that 15 isolates of the total (21) of Staphylococcus aureus gave a positive result for the examination of $\beta$-lactamase production with percentage (71.4\%) (Table 2), the results agree with Torimiro et al (28) pointed out that the $\beta$-lactamase production of S.aureus by $(70.1 \%)$.The results indicated that $5(23.80 \%)$ isolates were Metallo $\beta$-lactamase producers (Table 2), While 4(19.04\%) isolates of S.aureus were ESBLs producers.

Table (2): The percentages of S.aureus isolates $\beta$-lactamase, Metallo $\beta$-lactamase, ESBLs production.

\begin{tabular}{|c|c|c|}
\hline$\beta$-lactamase production & Number of isolates & Ratio \% \\
\hline$\beta$-lactamase & 15 & $71.4 \%$ \\
\hline Metallo $\beta$-lactamase & 5 & $23.80 \%$ \\
\hline ESBLs & 4 & $19.04 \%$ \\
\hline
\end{tabular}

\section{S. aureus Tolerance to Metal Salts}

The results shown in ( Table 3) indicate that 12 isolate (57.1\%) of S.aureus has the ability to tolerances $1.5 \mathrm{mM}$ of cobalt, this is the highest concentration of cobalt metal bacteria able to 
Heavy Metals Tolerance and Antibiotics Susceptibilty Profiles of Staphylococcus aureus Strains Isolated From Clinical Sources in Baquba city

\section{Lina Abdulameer Salman Alsaadi}

afford, while 3 isolates have the ability to tolerate low cocentration $0.5 \mathrm{mM}$ of metal with percentage (14.2\%). As for copper, the highest concentration was $3 \mathrm{mM}$, S.aureus isolates tolerant this metal by 11 isolates $(52.3 \%)$, whereas tolerance S.aureus lowest concentration $0.5 \mathrm{mM}$ by 4 isolates (19\%). Copper is associated with particular sites on any amino acid for microorganisms and restores oxidation-reduction cycle and generates free radical hydroxide near the binding sites this causing damage to amino acid (29). 14 isolates (66.6\%) of S.aureus tolerant a higher concentration of $3 \mathrm{mM}$ of iron, able 3 isolates (14.2\%) tolerant a lowest concentration $0.5 \mathrm{mM}$ of iron this results agrees with Singh et al. (12) pointed out that all S.aureus isolates were resistant to iron salts. The results for mercury demonstrated that (7) S.aureus isolates tolerant a higher concentration of $0.03 \mathrm{mM}$ of mercury with ratio $(33.3 \%)$ and 9 isolates tolerant $0.05 \mathrm{mM}$ of mercury with ratio (38.5\%). The results showed that 13 isolates $(61.9 \%)$ has ability to tolerant zinc metal with concentration $1.5 \mathrm{mM}$ (table 3$)$, While $(19 \%)$ of S.aureus tolerant lowest concentration $0.5 \mathrm{mM}$ of zinc. Samanta et al (30) have shown that microorganisms have the capacity to resist antibiotics and heavy metals, which may be extremely harmful to human being and animals. The resistance of bacteria to heavy metals may due to the presence of conjugative plasmid that mediates resistance to metals (31).

Table (3): Percentages of tolerance S.aureus isolates for heavy metals .

\begin{tabular}{|c|c|c|}
\hline Heavy metals & Concentration of heavy metals $(\mathrm{mM})$ & N0.\&Percentage (\%) of S.aureus isolates \\
\hline \multirow{3}{*}{ Cobalt $(\mathrm{Co})$} & 1.5 & $12(57.1 \%)$ \\
& 1 & $6(28.5 \%)$ \\
\hline \multirow{3}{*}{ Copper $(\mathrm{Cu})$} & 0.5 & $3(14.2 \%)$ \\
\hline \multirow{3}{*}{ Iron $(\mathrm{Fe})$} & 3 & $11(52.3 \%)$ \\
& 2 & $6(28.5 \%)$ \\
& 0.5 & $4(19 \%)$ \\
\hline \multirow{3}{*}{ Mercury $(\mathrm{Hg})$} & 3 & $14(66.6 \%)$ \\
& 0.5 & $4(19 \%)$ \\
\hline \multirow{2}{*}{ Zinc $(\mathrm{Zn})$} & 0.03 & $3(14.2 \%)$ \\
& 0.01 & $7(33.3 \%)$ \\
& 1.5 & $9(38.5 \%)$ \\
\hline
\end{tabular}


Heavy Metals Tolerance and Antibiotics Susceptibilty Profiles of Staphylococcus aureus Strains Isolated From Clinical Sources in Baquba city

\section{Lina Abdulameer Salman Alsaadi}

\section{The relationship between the isolates were resistant to heavy metals and antibiotics}

S.aureus isolates under study showed different responses to heavy metals and antibiotics ranged between sensitive and resistance to antibiotics . Isolates of S.aureus isolated from wound ( SW3) has ability to resistant 10 (90.9\%) antibiotic and tolerance five heavy metals ( $\mathrm{Co}, \mathrm{Cu}, \mathrm{Fe}, \mathrm{Hg}$, $\mathrm{Zn}$ ) by $100 \%$ ( Table 4 ), while anather isolates isolated from ear (SE8) resistance 5 antibiotics with ratio ( $45.4 \%$ ) and tolerance $2(40 \%)$ heavy metal (table 4 ). The interaction between heavy metals and antibiotic resistance are of three types : heavy metals interaction with antibiotic resistance genes or even their products, heavy metals interaction with antibiotic compounds and heavy metal interaction with bacterial properties like conjugation (32).

Table (4): Resistance ratios of $S$. aureus to antibiotics and heavy metals.

\begin{tabular}{|c|c|c|}
\hline S.aureus isolates & $\begin{array}{c}\text { No. of antibiotic resistance } \\
\text { with ratio }(\%)\end{array}$ & $\begin{array}{c}\text { No. of heavy metals tolerance } \\
\text { with ratio }(\%)\end{array}$ \\
\hline SW1 & $8(72.7 \%)$ & $5(100 \%)$ \\
\hline SW2 & $5(45.4 \%)$ & $3(60 \%)$ \\
\hline SW3 & $10(90.9 \%)$ & $5(100 \%)$ \\
\hline SW4 & $7(63.6 \%)$ & $4(80 \%)$ \\
\hline SW5 & $7(63.6 \%)$ & $4(80 \%)$ \\
\hline SW6 & $8(72.7 \%)$ & $4(80 \%)$ \\
\hline SW7 & $9(81.8 \%)$ & $5(100 \%)$ \\
\hline SE8 & $5(45.4 \%)$ & $2(40 \%)$ \\
\hline SE9 & $7(63.6 \%)$ & $4(80 \%)$ \\
\hline SE10 & $9(81.8 \%)$ & $5(100 \%)$ \\
\hline SE11 & $8(72.7 \%)$ & $3(60 \%)$ \\
\hline SE12 & $6(54.5 \%)$ & $3(60 \%)$ \\
\hline SU13 & $9(81.8 \%)$ & $4(80 \%)$ \\
\hline SU14 & $8(72.7 \%)$ & $5(100 \%)$ \\
\hline SU15 & $8(72.7 \%)$ & $5(100 \%)$ \\
\hline SU16 & $6(54.5 \%)$ & $4(80 \%)$ \\
\hline SP17 & $10(90.9 \%)$ & $3(60 \%)$ \\
\hline SP18 & $7(63.6 \%)$ & $3(60 \%)$ \\
\hline SP19 & $6(54.5 \%)$ & $3(60 \%)$ \\
\hline SP20 & $7(63.6 \%)$ & $4(80 \%)$ \\
\hline SB21 & $8(72.7 \%)$ & $4(80 \%)$ \\
\hline & &
\end{tabular}

\section{Plasmid profile of S.aureus}

Plasmid profile of four isolates has been investigated, especially those that showed tolerant of heavy metals and multiple resistance to antibiotics, the results showed that all isolates of S.aureus contained two bands of plasmid vary in size ( Figure 2).this results agreed partially with results of 
Heavy Metals Tolerance and Antibiotics Susceptibilty Profiles of Staphylococcus aureus Strains Isolated From Clinical Sources in Baquba city

Lina Abdulameer Salman Alsaadi

Obajuluwa et al (33) which found all S.aureus isolates containing two bands of plasmid and some isolates contained one mega plasmid.

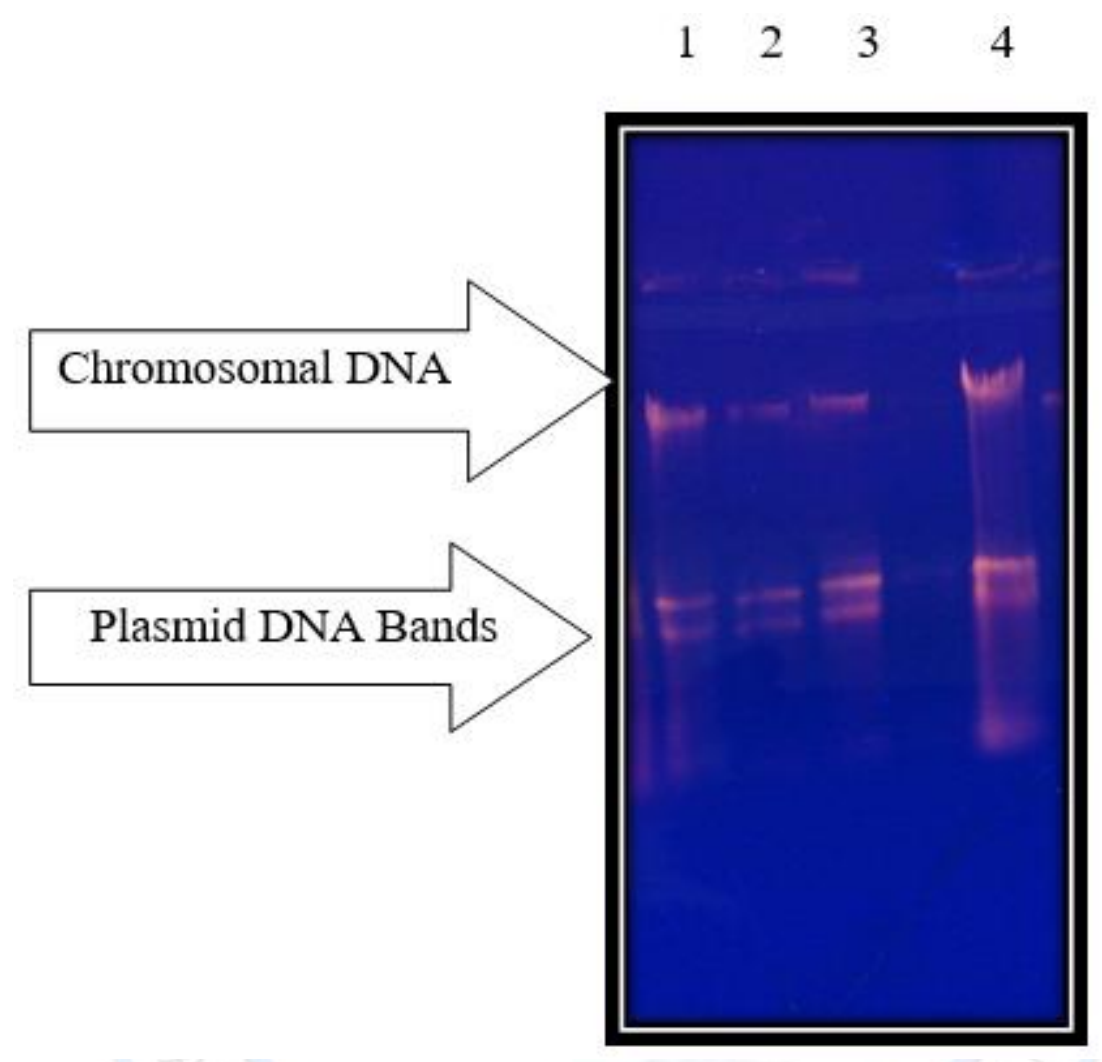

Figure (2): Agarose gel electrophoresis of plasmids from Staphylococcus aureus

(1) Plasmid content of SW3 isolate

(3)Plasmid content of SP10 isolate
(2) Plasmid content of SW7 isolate

(4) Plasmid content of SU15 isolate

\section{Curing of plasmid DNA}

Acridin orange was used in order to cure plasmids of Staphylococcus aureus isolates . The results showed the best concentration was $256 \mu \mathrm{g} / \mathrm{ml}$, which able to cure plasmids from all isolates . After the curing, the isolates were tested to antibiotic resistance and heavy metal tolerance, all isolates have not loss the ability to tolerate cobalt and zinc this mean that cobalt and zinc resistance gene was found to be present on the cheomosomal DNA rather than the plasmid DNA, while all isolates loss the capacity to tolerate iron , copper and mercury this due to its resistance genes were found to be present on the plasmid .Aditionaly results showed all four isolates lost the capacity to grow 


\section{Heavy Metals Tolerance and Antibiotics Susceptibilty Profiles of Staphylococcus aureus Strains Isolated From Clinical Sources in Baquba city}

\section{Lina Abdulameer Salman Alsaadi}

on medium containing cefotaxim, amoxicillin, erythromycin, and ciprofloxacin, this indicated that isolates contain genes on their plasmid.

\section{Conclusion}

The results suggest the possibility of isolating Staphylococcus aureus from different clinical sources . These isolates were resistant to many antibiotics, ( used drug of choise ) and tolerant of heavy metals . The tolerance of heavy metals and antibiotics was found to be both chromosomal as well as plasmid mediated in the isolates.

\section{References}

1. Taylor, A.R. (2013). Methicillin - resistant Staphylococcus aureus infections . primary care 40(3):637-654.

2. Zuniga, R. and Nguyen, T. (2013). Skin conditions: emerging drug-resistant skin infections and infestations. FP essentials 407: 17-23.

3. Akerele J and Ahonkhai IA. (2000) . Urinary pathogen and antibacterial susceptibility. A retrospective study of private diagnostic laboratory in Benin City, Nigeria.J.Med. Lab. Sci. 9:47-48.

4. Batabyal, B. ; Kundu, G. and Biswas, S. (2012). Methicillin resistant Staphylococcus. aureus : A Brief Review. International Research Journal of Biological Sciences : 1(7) : 65-71.

5. Imran , M. ; Imran, M. and Khan . S (2015). Multidrug resistance in Staphylococcus aureus isolates from clinical specimens in Northen India. African J. Microbial. Research. 9(51): 2396-2403.

6. Vidhani, S. ; Mendiratta, PL. and Mathur MD. (2001). Study of Methicillin resistant S. aureus from high risk patients. Indian J. Med. Microbial. 19(2):13-16.

7. Chambers HF (2001). The changing epidemiology Staphylococcus aureus . Emerg. Infect. Dis. 7:178-182.

8. Issazadeh, K. ; Jahanpour, N. ; Pourghorbanali, F. ; Raeisi, G. and Faekhondeh, J. (2013). Heavy metals resistance by bacterial strains. Ann. Biol. Res.4(2):60-63. 
Heavy Metals Tolerance and Antibiotics Susceptibilty Profiles of Staphylococcus aureus Strains Isolated From Clinical Sources in Baquba city

Lina Abdulameer Salman Alsaadi

9. Tamer, A. ; Aysenur ,K. and Sadik, D.(2013). Antibiotic Levels and Heavt Metal Resistance in Gram-Negative Bacteria Isolated from Seawater, Iskenderum Organized Industerial Zone . J. Applied Biological Sciences , 7:10-14.

10. Nikaido, H. (2009). Multidrug Resistance in Bacteria. Annual Review of Biochemstry, 78:119-146.

11. Lim, C.K. ; Hassan, K.A ; Penesyan , A. ; Loper, JE. And Paulsen, I.T.(2013). The effect of zinc limination on the transcriptome of Pseudomonas protegens Pf-5. Enviromental Microbiology. 15(3):702-715.

12. Singh, A. ; Mishra, M. ; Tripathi, P. and Sachan, S.(2015). Resistance of Heavy Metals on some Pathogenic Bacterial Spices. African Journal of Microbiology Research , 9: 11621164.

13. Rajbanshi, A. (2008). Study of Heavy Metal Resistant Bacteria in Guheswori Sewage Treatment Plant. Our Nature, 6:52-57.

14. Nageswaran, N. ; Ramteke, PW. ; Verma, OP. and Pande , A (2012). Antibiotic Susceptibility and Heavy Metal Tolerance Pattern of Serratia marcescens Isolated from Soil and Water. J. Bioremediation\&Biodegradation , 3, 158.

15. Nyamboya, R.A. ; Okemo, P.O. and Ombori, O. (2013).Heavy Metal and Associated Antibiotic Resistance of Fecal Coliforms , Fecal Streptococci and Pathogens Isolated from Wastewaters of Abattoirs in Nairobi, Kenya. Journal of Applied Biosciences, 64:4858-4866.

16. Nies , D.H. (1992). Resistance To Cadmium , Cobalt, Zinc And Nickel In Microbes." Plasmid 27 (1):17-28.

17. Washington, CW. ; Stephen, DA. ; William, MJ. ; Elmer, WK. ; Paul, CS. ; Gray, WP. and Gail, LW. (2006). Gram positive cocci . Koneman's Color Atlas and Textbook of Diagnostic Microbiology. 6t edition. Philadelphia: Lippincott Williams \&Williams 12:623-671.

18. CLSI(Clinical and Laboratory Standers Institute)(2010).Performance Standards for Antimicrobial Susceptibility Testing ; 20th Informational supplement, Clinical and Laboratory Standers Institute Wayane, PA: M100-S20:30(1). 
Heavy Metals Tolerance and Antibiotics Susceptibilty Profiles of Staphylococcus aureus Strains Isolated From Clinical Sources in Baquba city

Lina Abdulameer Salman Alsaadi

19. Shittu, A. ; Lin, J. and Kolawole, DO. (2006). Antimicrobial susceptibility patterns of Staphylococcus aureus and characterization of MRSA in South Western Nigeria. WOUNDS. 18(4): 77-84.

20. Who .( 1978). Techniques for the detection of $\beta$-Lactamase producing strains of Neisseria gonorrhoae. 616: 137-143.

21. Bhalerao, D.S. ; Roushani, S. ; Kinikar, A.G. and Akhter, I. (2010). Study of Metallobetalactamase producing Pseudomonas aeruginosa in Pravara Rural Hospital. Pravara Med Rev ;pp 1-5.

22. Jarlier , V. ; Nicolas, M. ; Fournier, G. and Philippon, A. (1988). Extended broud-spectrum $\beta$-Lactamases conferring transferable resistance to newer $\beta$-Lactam agents in Enterobacteriaceae: Hospital prevalence and susceptibility patterns . Rev. Infect. Dis. 10(4):867-878.

23. Singh , V. ; Chauhan, PK. ; Kanta, R. ; Dhewa, T. and Kumar, V.(2010). Isolation and Characterization of Pseudomonas Resistant to Heavy Metals Contaminations. Int. J. Pharma. Scie. Rev. Res. 3:164-167.

24. Sambrook,J. ; Fritsch , E.F. and Maniatis, T.(1989). Molecular Cloning : A Laboratory Manual. 2nd ed. Cold Spring Harbor, N.Y.

25. Obiazi, H.A. ; Nmorsi, O.P. ; Ekundayo, A.O. and Ukwandu, N.C. (2007). Prevalence and antibiotic susceptibility pattern of Staphylococcus aureus fromclinical isolates grown at 37 and $44^{\circ} \mathrm{C}$ from Irrua, Nigeria. African J. Micro. Res. pp:057-060.

26. El-Gayar , M.H. ; Aboulwafa, M. ; Aboshanab , K.M. and Hassouna, N.A. (2014). Virulance characters of some methicillin resistant Staphylococcus aureus isolates. MedPub Journals. 5.4:3.3823-3843.

27. Livermore DM. (2002). Multiple mechanisms of antimicrobial resistance in Pseudomonas aeruginosa: our worst nighmare? Clinical Infectious Diseases, 34:634-640.

28. Torimiro , N. ; Moshood, AA. And Eyiolawi , SA.(2013). Analysis of Beta-lactamase production and Antibiotics resistance in Staphylococcus aureus strains. J. Infe. Dise\&Immu.5(3):24-28. 
Heavy Metals Tolerance and Antibiotics Susceptibilty Profiles of Staphylococcus aureus Strains Isolated From Clinical Sources in Baquba city

\section{Lina Abdulameer Salman Alsaadi}

29. Borkow , G. and Gabbay, J.(2005). Copper as a biocidal tool. Current Medicinal Chemistry , 12:2163-2175.

30. Samanta, A. ; Bera, P. ; Khatun, M. ; Sinha, C. ; Pal, P. ; Lalee, A. and Mandal, A. (2012). An investigation on heavy metal tolerance and antibiotic resistance properties of bacterial strain Bacillus sp.isolated from municipal waste. J. Microbiol. Biotechnol.Res. 2(1):178189.

31. Egbeb , A.O. and Famurewa, O.(2011). Heavy Metal Resistance among Klebsiella Isolates in some parts of Southwest, Nigeria. Asi.J.of Medical Sciences 3(5):183-185.

32. Nishino , K. ; Nikaido, E. and Yamaguchi, A. (2007). Regulation of multidrug efflux systems involved in multidrug and metal resistance of Salmonella enteric serovar Typhimurium. Journal of Bacteriology .189: 9066-9075.

33. Obajuluwa, A.F. ; Olayinka, B.O. ; Adeshina, G.O. ; Onaolapo, J.A. and Afolabi-Balogun, N.B. (2015). Plasmid profile of Staphylococcus aureus from orthopaedic patients in Ahmadu Bello University Teaching Hospital Zaria, Nigeria.African. J. Micro.Research. 9(33):19411946. 